\title{
HUBUNGAN PENGETAHUAN DENGAN TINGKAT KECEMASAN IBU YANG ANAKNYA DI RAWAT RSUP PROF. DR. R. D. KANDOU MANADO
}

\author{
${ }^{1}$ Putu Agus Rinaldi \\ ${ }^{2}$ H. Opod \\ ${ }^{2}$ Cicilia Pali
}

\author{
${ }^{1}$ Kandidat Skripsi Fakultas Kedokteran Universitas Sam Ratulangi Manado \\ ${ }^{2}$ Bagian Psikologi Fakultas Kedokteran Universitas Sam Ratulangi Manado \\ Email: Putuagusrinaldy@yahoo.com
}

\begin{abstract}
Knowledge is the result of the idea and someone did this happen after sensing on a particular object. Anxiety is a normal thing that happens in the growth, changes, new experiences and discoveries can accompany meaning of life and self-identity. The higher one's education will be more easily and able to deal with stress.Individually anxious can interfere especially with the lack of knowledge of the problems faced. The purpose of this study is to find the relationship of knowledge about dengue fever with a mother whose son is anxiety levels treated parts department Prof children Dr. R. D. Kandou Manado. This study used a questionnaire rating their knowledge and Hamilton Anxiety Scale (HARS) with a sample of 71 respondents.Based on the results of the study found that there are 32 good knowledgeable mothers (45,07\%) were knowledgeable mothers 39 (54,93\%). While there were 59 maternal anxiety $(83,10 \%)$ severe anxiety, there were 12 mothers (16,90\%). Based on statistics by using Fisher's Exact Test is used as an alternative test of the Chi Square test are not eligible where one column value must be at least 5,41. Based on the analysis at $95 \%$ confidence level and error rate $\alpha=0.05$ shows the $\mathrm{p}$-value $=0.000<\alpha=0.05$ level. Therefore we can conclude that $\mathrm{H} 0$ is rejected and Ha is accepted that there is a significant correlation between maternal knowledge about dengue fever with maternal anxiety levels that treated her son Prof parts. Dr. R. D. Kandou Manado.
\end{abstract}

Keyword: Knowledge, Anxiety, DBD

\begin{abstract}
Abstrak: Pengetahuan adalah hasil dari tahu dan ini terjadi setelah orang melakukan penginderaan pada suatu objek tertentu. Kecemasan adalah sesuatu yang normal terjadi dalam pertumbuhan, perubahan, pengalaman baru dan dapat menyertai penemuan arti hidup dan identitas diri. Semakin tinggi pendidikan seseorang akan semakin mudah dan mampu menghadapi stres yang ada. Secara individu cemas dapat mengganggu apa lagi disertai dengan pengetahuan yang kurang terhadap masalah yang dihadapi. Tujuan penelitian ini adalah untuk mencari hubungan pengetahuan tentang demam berdarah dengue dengan tingkat kecemasan ibu yang anaknya di rawat RSUP. Prof. Dr. R. D. Kandou Manado. Penelitian ini menggunakan kuesioner Pengetahuan dan Hamilton Anxiety Rating Scale (HARS) dengan jumlah sampel 71 responden. Berdasarkan hasil penelitian ditemukan, yang berpengetahuan baik ada 32 ibu (45,07\%), berpengetahuan sedang 39 ibu (54,93\%). Sedangkan kecemasan sedang ada 59 ibu (83,10\%), kecemasan berat ada 12 ibu (16,90\%). Berdasarkan statistik dengan menggunakan Uji Fisher Exact yang digunakan sebagai Uji alternative dari Uji Chi Square Test yang tidak memenuhi syarat dimana salah satu nilai kolomnya harus minimal 5,41. Berdasarkan hasil analisis pada tingkat kepercayaan $95 \%$ dan tingkat kesalahan $\alpha=0,05$ menunjukkan nilai $\mathrm{p}=$ $0,000<\alpha=0,05$. Sehingga dapat disimpulkan bahwa H0 ditolak dan Ha diterima yaitu terdapat hubungan yang bermakna antara pengetahuan ibu tentang demam berdarah dengue dengan tingkat kecemasan ibu yang anaknya di rawat RSUP. Prof. Dr. R. D. Kandou Manado.
\end{abstract}

Kata kunci: Pengetahuan, Kecemasan, DBD 
Kasus demam berdarah dengue di Asia Tenggara terjadi peningkatan terutama pada anak-anak selama 5 tahun terakhir. Diperkirakan 500 kasus DBD terjadi tiap tahunnya, dimana 90\% dari kasus tersebut menyerang anak-anak dibawah umur 15 tahun.,

DBD merupakan salah satu penyakit mematikan di Indonesia dan memerlukan penanganan penting. ${ }^{2}$ DBD merupakan penyakit infeksi yang disebabkan oleh virus dengue dengan tanda-tanda klinis berupa demam, nyeri sendi dan ruam merah dibawah kulit. ${ }^{1}$ Di Indonesia jumlah kasus DBD cenderung meningkat tiap tahunnya serta bertambahnya wilayah yang terjangkit karena kurangnya perilaku masyarakat terhadap pembersihaan sarang nyamuk. ${ }^{3}$

Berdasarkan laporan hasil Riset Kesehatan Dasar (RIKESDAS) pada tahun 2008, penyakit DBD masuk dalam sepuluh besar penyakit menular di Sulawesi Utara dengan jumlah kesehatan 701 orang. ${ }^{4}$

Pengetahuan merupakan hasil dari tahu dan ini terjadi melalui panca indera manusia. Pengetahuan tentang DBD sangat penting diberitahukan kepada orang tua agar mereka lebih tahu tentang penyakit anaknya. Pengetahuan sangat mempengaruhi seseorang dalam menghadapi suatu masalah.,

Menurut beberapa hasil penelitian tentang pengaruh pengetahuan terhadap kecemasan pada orang tua, menunjukkan orang tua yang memiliki pengetahuan tentang penyakit anaknya cenderung memiliki kecemasan ringan dibandingkan dengan orang tua yang memilki pengetahuan kurang tentang penyakit anaknya. ${ }^{7,8}$

Berdasarkan uraian diatas penulis tertarik untuk mengetahui hubungan pengetahuan tentang demam berdarah dengue dengan tingkat kecemasan ibu yang anaknya di rawat RSUP Prof. Dr. R. D. Kandou Manado.

\section{METODE PENELITIAN}

Penelitian ini menggunakan metode survey analitik dengan pendekatan cross sectional, Penelitian analitik bertujuan untuk mengetahui hubungan antar variabel. Waktu penelitian dilakukan pada bulan Oktober
2012-Januari 2013 dan tempat penelitian ini dilaksanakan (di Irina E) RSUP Prof. Dr. R. D. Kandou Manado. Populasi yang di gunakan penelitian ini adalah seluruh ibu yang anaknya terkena penyakit DBD di RSUP Prof. Dr. R. D. Kandou Manado. Sedangkan sampel penelitian ini berjumlah 71 orang. Semua yang memenuhi.

Kriteria Inklusi, yaitu ibu yang bersedia menjadi responden penelitian, ibu yang anaknya berstatus sebagai pasien baru minimal 1 hari, ibu yang anaknya berumur 0-15 tahun kebawah, ibu yang bersedia ikut serta menandatangani informed consent, dan mengisi kuesioner pengetahuan dan Hamilton Anxiety Rating Scale (HARS). Yang menjadi variabel penelitian ini Pendidikan, Umur, Pengetahuan, dan Kecemasan dengan menggunakan aplikasi Statiscal and Survise Solution (SPSS 17.0).

\section{HASIL PENELITIAN}

Dari penelitian yang dilakukan di RSUP Prof. Dr. R. D. Kandou Manado didapatkan hasil sebagai berikut:

Tabel 1. Distribusi frekuensi menurut tingkat pendidikan responden

\begin{tabular}{ccc}
\hline $\begin{array}{c}\text { Tingkat } \\
\text { Pendidikan }\end{array}$ & Frekuensi & Persentase (\%) \\
\hline SD & 20 & 28,17 \\
SMP & 27 & 38,03 \\
SMA & 18 & 25,35 \\
Perguruan & 6 & 8,45 \\
Tinggi & & \\
\hline Total & 71 & 100 \\
\hline
\end{tabular}

Berdasarkan Tabel diatas menunjukkan bahwa tingkat pendidikan yang paling banyak adalah SMP (38,03\%), sedangkan tingkat pendidikan paling sedikit adalah Perguruan Tinggi (8,45\%).

Tabel 2 menunjukan bahwa tingkat pengetahuan baik sebanyak 32 responden (45,07\%) dan tingkat pengetahuan sedang sebanyak 39 responden (54,93\%). 
Tabel 2. Skor tingkat pengetahuan ibu tentang demam berdarah dengue

\begin{tabular}{ccc}
\hline $\begin{array}{c}\text { Tingkat } \\
\text { Pengetahuan }\end{array}$ & Frekuensi & Persentase (\%) \\
\hline Baik & 32 & 45,07 \\
Sedang & 39 & 54,93 \\
Kurang & 0 & 0 \\
\hline Total & 71 & 100 \\
\hline
\end{tabular}

Tabel 3. Skor Tingkat kecemasan ibu

\begin{tabular}{lcc}
\hline $\begin{array}{c}\text { Tingkat } \\
\text { Kecemasan }\end{array}$ & Frekuensi & Persentase (\%) \\
\hline Ringan & 0 & 0 \\
Sedang & 59 & 83,10 \\
Berat & 12 & 16,90 \\
\hline \multicolumn{1}{c}{ Total } & 71 & 100 \\
\hline
\end{tabular}

Berdasarkan Tabel diatas menunjukkan bahwa kecemasan ibu paling banyak berada pada kecemasan sedang yaitu 59 responden $(83,10 \%)$ dan cemas berat 12 responden $(16,90 \%)$.

Tabel 4. Hubungan pengetahuan dengan tingkat kecemasan ibu yang anaknya dirawat RSUP Prof. Dr. R. D. Kandou Manado.

\begin{tabular}{ccccc}
\hline \multirow{2}{*}{ Tingkat } & \multicolumn{4}{c}{ Tingkat Pengetahuan } \\
\cline { 2 - 5 } Kecemasan & Baik & Sedang & Kurang & Jumlah \\
\hline Tidak & 0 & 0 & 0 & 0 \\
cemas & 0 & 0 & 0 & 0 \\
$\begin{array}{c}\text { Cemas } \\
\text { ringan }\end{array}$ & 0 & 27 & 0 & 59 \\
$\begin{array}{c}\text { Cemas } \\
\text { sedang }\end{array}$ & 32 & 12 & 0 & 12 \\
$\begin{array}{c}\text { Cemas } \\
\text { berat }\end{array}$ & 0 & 39 & 0 & 71 \\
\hline Jumlah & 32 & &
\end{tabular}

Berdasarkan tabel diatas menunjukkan bahwa terdapat 32 responden yang pengetahuan baik dengan kecemasan sedang, pengetahuan sedang dengan kecemasan sedang 27 responden, dan 12 responden pengetahuan sedang dengan kecemasan berat.

\section{BAHASAN}

Faktor usia adalah salah satu faktor yang masih diperdebatkan kaitannya dengan tingkat pengetahuan dan kecemasan. Ada pendapat yang menyatakan bahwa orang berusia muda lebih mudah mengalami kecemasan, namun ada juga yang berpendapat sebaliknya. Pada penelitian ini usia responden tidak dicari hubungannya dengan tingkat kecemasan, namun sebagai kelengkapan data untuk menunjukkan karakteristik sampel penelitian yang diharapkan dapat mewakili karakteristik populasi. Dalam penelitian ini seluruh responden berusia di atas 20 tahun, sebagian besar berusia 20-24 tahun, dimana pada tahap ini seorang wanita biasanya sudah mempunyai anak, sehingga ini menggambarkan karakteristik populasi yaitu semua ibu yang anaknya terkena penyakit DBD di RSUP Prof. Dr. R. D. Kandou Manado.

Distribusi frekuensi responden berdasarkan tingkat pendidikan pada penelitian ini menunjukkan bahwa dari 71 responden, sebagian besar hanya mengenyam tingkat pendidikan dasar (SD, SMP dan SMA), sedangkan responden yang mengenyam pendidikan di perguruan tinggi hanya 6 responden (8,45\%). Tingkat pendidikan formal merupakan dasar pengetahuan intelektual yang dimiliki seseorang. Hal ini erat kaitannya dengan pengetahuan karena semakin tinggi pengetahuan semakin besar kemampuan menyerap dan menerima informasi sehingga pengetahuan dan wawasan lebih luas. ${ }^{6}$

Sebagian besar tingkat pendidikan responden adalah SMP (27 responden; 38,03\%), diikuti dengan SD (20 responden; 28,17\%). Hal ini menjadi menarik karena berdasarkan penelitian yang dilakukan, tingkat pengetahuan keseluruhan responden sudah cukup baik, yaitu tingkat pengetahuan baik ada 32 responden (45,07\%) dan tingkat pengetahuan sedang ada 39 responden (54,93\%), tidak ada responden dengan tingkat pengetahuan rendah. Hal ini memberikan gambaran bahwa tingkat pendidikan responden bukan satu-satunya faktor yang mempengaruhi tingkat pengetahuan responden tentang DBD. 
Pendidikan, pengalaman dan sumber informasi adalah faktor-faktor yang mempengaruhi pengetahuan seseorang, namun penelitian ini tidak meneliti tentang pengalaman ataupun sumber informasi dan kaitannya dalam menentukan tingkat pengetahuan responden. Tingginya kejadian DBD di Sulawesi Utara dapat berkontribusi besar dalam meningkatkan pengetahuan responden melalui pengalaman karena DBD bukanlah suatu hal yang jarang dijumpai di masyarakat. Informasi mengenai dapat diperoleh baik melalui media cetak maupun melalui media elektronik serta penyuluhan dari kader kesehatan. Semakin banyak informasi yang diperoleh maka semakin meningkat pula pengetahuan ibu tentang DBD. ${ }^{5,9}$

Tingkat kecemasan responden yang diteliti hanya terbagi dalam dua tingkatan yaitu cemas sedang dan cemas berat. Dari keseluruhan responden yang paling banyak yaitu tingkat kecemasan sedang (59 responden; 83,1\%), sedangkan tingkat kecemasan berat hanya dialami oleh 12 responden (16,90\%). Tidak ditemukan responden dengan tingkat kecemasan ringan, sehingga dapat disimpulkan bahwa DBD adalah penyakit yang menimbulkan kecemasan dalam tingkat sedang hingga berat pada ibu pasien DBD. Hal ini dapat dipahami karena DBD adalah salah satu penyakit dengan tingkat kematian yang tinggi, sehingga ketakutan akan kematian anak dapat membawa sang ibu dalam tingkat kecemasan sedang hingga berat. Temuan ini sesuai dengan teori yang menyatakan bahwa salah satu penyebab timbulnya kecemasan adalah ketika menghadapi risiko kematian diri sendiri atau pada orang yang memiliki kedekatan hubungan. ${ }^{8,10}$

Tabulasi silang yang dilakukan untuk proses analisis statistik menunjukkan bahwa seluruh responden dengan tingkat pengetahuan baik hanya mengalami tingkat kecemasan sedang, sedangkan sekitar sepertiga responden dengan tingkat pengetahuan sedang mengalami tingkat kecemasan berat. Hasil ini menggambarkan bahwa ada hubungan antara tingkat pengetahuan dan tingkat kecemasan, yaitu semakin tinggi tingkat pengetahuan responden maka tingkat kecemasannya semakin rendah. Dengan kata lain, ibu yang mengetahui tentang DBD dengan baik akan lebih ringan tingkat kecemasannya dibandingkan dengan ibu yang tidak mengetahui tentang DBD dengan baik, hal inilah yang diuji lebih lanjut.

Untuk mengetahui hubungan pengetahuan tentang DBD dengan tingkat kecemasan responden yang telah dituangkan dalam hipotesis maka hasil penelitian kemudian dianalisis secara statistik. Uji Fisher Exact Test digunakan sebagai uji alternatif dari Uji Chi Square Test yang tidak memenuhi syarat dimana salah satu nilai kolomnya harus minimal 5,41. Berdasarkan hasil analisis pada tingkat kepercayaan $95 \%$ dan tingkat kesalahan $\alpha=$ $0,05(5 \%)$ menunjukkan nilai $\mathrm{p}=0,000<\alpha$ $=0,05 .{ }^{6}$ Sehingga dapat disimpulkan bahwa H0 ditolak dan Ha diterima yaitu terdapat hubungan yang bermakna antara tingkat pengetahuan tentang DBD dengan tingkat kecemasan ibu yang anaknya di rawat RSUP Prof. Dr. R. D. Kandou Manado.

\section{SIMPULAN}

Berdasarkan hasil penelitian yang di lakukan RSUP Prof. Dr. R. D. Kandou Manado dengan jumlah sampel 71 responden. Presentase ibu yang paling banyak yaitu ibu yang berpengetahuan sedang yaitu 54,93\% (39 ibu) dan berpengetahuan baik 45,07\% (32 ibu). Sedangkan presentase ibu yang mengalami kecemasan sedang paling banyak yaitu 83,10\% dan kecemsan berat 16,90\%. Dan terdapat hubungan yang signifikan antara pengetahuan ibu dengan tingkat kecemasan yang anaknya di rawat RSUP Prof Dr. R. D. Kandou Manado.

\section{DAFTAR PUSTAKA}

1. Adinugraha F. Memberikan Pelayanan Kesehatan Kepada Masyarakat di Alur Sungai Citarum. Puskesmas Pebayuran; 2008.

2. Thu, H. M. K. Lowry, T. T. Myint, et al Myanmar Dengue Outbreak Associated wid Displacement of serotype 2, 3, and 4 by 
Dengue 1. Emerg. Infection.10.h.593-97

3. Rusnato. Hubungan Keberadaan Larva di Container Sebelah Rumah Tngga dengan Kejadian DHF di Rumah Sakit Islam Sunan Kudus; 2010.

4. Nurfadly. Deteksi dan Penentuan serotype virus dengue tipe 1 dari nyamuk aedes aegypti dengan menggunakan reverse transciptase polymerase chain reaction (RT PCR) [Tesis]. Medan; 2009,h.18

5. Natoatmodjo S. Promosi Kesehatan dan Ilmu Perilaku. Jakarta: Rineka Cipta, 2007; h.139-50.

6. Suparyanto. Konsep Kecemasan. Blongspot. 2011.h.3-4
7. Indrayani A. hubungan Pendidikan Kesehatan dengan Tingkat Kecemasan Orang Tua Terhadap Anaknya Di rawat. 2012.h.4-7

8. Wahyuningsih P. Tingkat Kecemasan Orang Tua Terhadap Anak Mengalami Hospitalisasi Diruang Wawar RSI Giodanglengi. Malang; 2008.h.1

9. Randonuwu M. R. Profil Kesehatan Provinsi Sulawesi Utara tahun 2008. Sulut Sehat; 2008.h.21-8

10. Wong DL, Hockenberry-Eaton M, Wilson D, Winkelstein M.L, Schwartz P. Buku Ajar Keperawatan Pediatrik. Jakarta: Penerbit Buku Kedokteran EGC, 2002; h.753-64. 